ETNIK : Jurnal Ekonomi - Teknik

ISSN: 2808-6694 (Online);2808-7291 (Print)

Jurnal Homepage https://etnik.rifainstitute.com

\title{
PENGARUH IKLAN CASH CARD TERHADAP MINAT MAHASISWA FEBI UIN SUMATERA UTARA
}

\begin{abstract}
Aula Maulidah
UIN Sumatera Utara
\end{abstract}

\section{Informasi Artikel}

Histori Artikel:

Diterima

Direvisi

Diterbitkan

10 Desember 2021

15 Desember 2021

20 Desember 2021

Email Author:

aula27042001@gmail.com

\begin{abstract}
This research is motivated by increasingly rapid technological developments, especially in the economic field, namely the payment system. The card acts as a non-cash payment instrument and makes it easier for the public to make transactions or transfers between individuals. This shows that people have switched from cash payments to non-cash payments which will have an impact on the current formula for money supply. Stability of money demand in potential member states is imperative for the feasible common monetary policy. This study aims to determine the level of influence of cash card advertising (atm card) on the interest of Islamic economics students at UIN North Sumatra and to determine whether or not there is an effect of cash card advertising on the interests of students of Febi UIN North Sumatra. The research method used is a quantitative method. Collecting data distributing respondents Islamic economics S1 Stambuk 2019.. Research data collection uses the questionnaire method with the Likert scale method and is given to 100 respondents. In this study, the data analysis techniques used were descriptive analysis and uji t using SPSS 15.0. The results of this study indicate that the effect of cash card advertising on the interest of Islamic economics students at FEBI UIN North Sumatra is $15.49 \%$. After passing several tests, it can be concluded that the effect of cash card advertising is significant or there is a positive influence on student interest.
\end{abstract}

Keyword-Advertising effect, Cash card, Interest

\begin{abstract}
ABSTRAK
Penelitian ini dilatarbelakangi oleh perkembangan teknologi yang semakin pesat terutama dalam bidang ekonomi yaitu sistem pembayaran. Kartu berperan sebagai alat pembayaran non tunai dan memudahkan masyarakat dalam melakukan transaksi atau pun transfer antar individu. Hal ini menunjukkan bahwa masyarakat telah beralih dari pembayaran tunai ke pembayaran non tunai yang akan berdampak pada jumlah rumus uang beredar saat ini. Stabilitas permintaan uang merupakan unsur penting dalam memelihara
\end{abstract}


kestabilan ekonomi efektivitas kebijakan moneter. Penelitian ini bertujuan untuk mengetahui seberapa besar tingkat pengaruh iklan cash card ( kartu atm) pada minat mahasiswa ekonomi islam UIN sumatera utara dan untuk mengetahui ada atau tidaknya pengaruh iklan cash card terhadap minat mahasiswa febi UIN sumatera utara dengan studi kasus mahasiswa ekonomi islam S1 angkatan 2019. Metode penelitian yang digunakan metode kuantitatif. Pengambilan data dengan cara menyebarkan kuesioner melalui google form dengan responden mahasiswa ekonomi islam S1 stambuk 2019. Pengumpulan data penelitian menggunakan metode kuesioner dengan metode skala likert dan diberikan kepada 100 responden. Dalam penelitian ini teknik analisis data yang digunakan yaitu analisis deskriptif dan uji t menggunakan SPSS 15.0. Hasil dari penelitian ini menunjukkan bahwa pengaruh iklan cash card terhadap minat mahasiswa ekonomi islam FEBI UIN sumatera utara diketahui sebesar $15,49 \%$. Setelah melewati beberapa uji dapat disimpulkan bahwa pengaruh iklan cash card signifikan atau adanya pengaruh positif terhadap minat mahasiswa.

Kata Kunci - Pengaruh iklan, Cash card, Minat

\section{PENDAHULUAN}

Dalam kehidupan sehari-hari manusia selalu berusaha untuk terus memenuhi kebutuhannya karena pada dasarnya manusia sebagai makhluk yang tidak pernah puas. Salah satu kegiatan pemenuhan kebutuhan manusia ialah kegiatan konsumsi yang didasari oleh faktor-faktor pendukung yang mencakup pendapatan yang tinggi dan kebiasaan gaya hidup konsumen (Solihat and Arnasik 2018).

semenjak terbitnya SK Menteri Keuangan No. 1251 / KMK.013 / 1988 tanggal 20 Desember 1988, penggunaan kartu plastik di Indonesia semakin meluas. Kartu plastik ini artinya pengganti alat pembayaran yang sangat praktis sehingga diminati warga yang berpenghasilan cukup atau kalangan menengah atas serta juga diminati sang mahasiswa (Iska 2012).

Iklan menurut PPPI ialah Segala bentuk pesan tentang suatu produk disampaikan melalui suatu media, dibiayai oleh pemrakarsa yang dikenal, serta ditujukan kepada sebagian atau seluruh masyarakat. Sedangkan menurut kamus besar bahasa indonesia Pemberitahuan kepada khalayak mengenai barang dan jasa yang dijual, dipasang di media massa seperti koran dan majalah, atau di tempat-tempat umum (Purwaningwulan 2013).

Iklan (advertisement) adalah produk yang dihasilkan dari kegiatan beriklan. Jadi iklan adalah produknya (barangnya,pesannya,dan bendanya) sedangkan periklanan adalah proses kegiatan, mulai dari merancang, membuat hingga kampanye iklan ke masyarakat. Periklanan adalah segala bentuk komunikasi non personal yang membayar tentang ide-ide, barang atau jasa yang disampaikan melalui saluran media yang terseleksi (advertising is any paid form of nonpersonal communication of ideas, goods or services delivered through selected media channels) (Rahman et al. 2010).

Kartu ATM, kartu debet, dan kartu kredit diatur dalam PBI nomor 11/11/PBI 2009 tentang penyelenggaraan kegiatan APMK. BI menetapkan maksimum suku bunga yaitu sekitar tiga persen perbulan untuk pembelanjaan. Seiring berkembangnya zaman alat pembayaran terus berkembang dari alat pembayaran tunai (cash) ke alat pembayaran nontunai (noncash). Peredaran kartu 
ATM/debet selama tahun 2010 sekitar 51,6 juta kartu, volume penggunaan kartu ATM/debit yang mencapai 1,81 milyar transaksi atau 4,95 juta transaksi perhari, menjadi yang paling tinggi diantara pembayaran lainnya.

Namun dengan demikian, peningkatan kartu ATM/ debet meningkatkan pula resiko yang disebabkan kelalaian pengguna ataupun disebabkan fraud (kejahatan) yang dilakukan oleh pihak yang tidak bertanggung jawab.

Terkait hal ini bank indonesia sudah mengatur dalam undang-undang nomor 2 tahun 1992 dan telah diubah menjadi undang-undang nomor 10 tahun 1998 tentang perbankan. Kehilangan dana nasabah juga sudah diatur dalam peraturan bank indonesia (PBI) no. 7/PBI/2005 tanggal 20 januari tentang "Transparansi informasi produk bank dan penggunaan data pribadi nasabah. PBI no. 7/7/PBI/2005 tanggal 20 januari tentang "Penyelesaian pengaduan nasabah". PBI No. 8/5/PBI/2006 tanggal 30 januari tentang "Mediasi perbankan". Semua peraturan dibuat untuk merealisasikan kegiatan usaha perbankan dengan ketentuan undang-undang dalam menyetarakan antara pelaku usaha dan konsumen atau nasabah.

Alat pembayaran non cash terdiri dari :

1. Alat pembayaran menggunakan kertas (paper based) seperti cek dan bilyet giro.

2. Alat pembayaran tanpa kertas (paperless) seperti transfer dana elektronik.

3. Alat pembayaran menggunakan kartu (card-based) yaitu kartu ATM, kartu debit, kartu kredit, dan kartu prabayar.

Hadirnya wahana jual beli serta transaksi online saat ini menghadirkan sikap konsumen dan usaha yg serba praktis dan instan. Oleh karena itu bermunculan berbagai macam metode pembayaran transaksi keuangan non tunai salah satunya yg menjadi pilihan ialah cash card (ATM). cash card (ATM) saat ini dianggap sebagai alat satu bagian dari gaya hayati rakyat terkini.

Pihak perbankan sangat gencar pada memasarkan cash card (ATM ) kepada konsumen menggunakan fasilitas yang menggiurkan. Penggunaan cash card (ATM) memerlukan tingkat kepercayaan yg tinggi dari penggunanya. banyak kemudahan serta potongan yang diberikan sang pihak perbankan. oleh karena itu pihak perbankan wajib melakukan pengawasan serta pemantauan yang ketat terhadap pengguna cash card (ATM).

Di Dalam bahasa inggris minat dikenal sebagai interest. Minat merupakan ketertarikan suatu aktivitas tertentu. Menurut savickas dan spokane, minat adalah sikap (attitude) atau perasaan senang (feeling) pada suatu objek atau event tertentu. (Slameto dalam Asmani 2009) mengatakan bahwa: "Minat adalah rasa lebih suka dan ketertarikan pada suatu hal atau aktivitas tertentu, tanpa ada yang menyuruh". Demikian di dalam jiwa seseorang yang memperhatikan sesuatu ia mulai dengan menaruh minat terhadap hal itu. Minat itu erat hubungannya dengan kepribadian seseorang ketiga fungsi jiwa: kognisi, emosi dan konasi terdapat dalam minat kadang minat itu timbul dengan sendirinya, dan kadang-kadang perlu diusahakan.

\section{METODE}

Penelitian ini digolongkan sebagai penelitian kuantitatif. Metode Penelitian kuantitatif menurut sugiyono merupakan salah satu jenis yang spesifikasi nya adalah sistematis, terencana dan terstruktur dengan jelas sejak awal hingga pembuatan desain penelitian (Indah 2016). Metode Penelitian deskriptif ini dilakukan untuk mengetahui keberadaan variabel mandiri, baik hanya pada satu variabel atau lebih tanpa membuat perbandingan dengan variabel lain (Jayusman and Shavab 2020). 
Penelitian ini dilakukan secara online melalui google form. Penelitian Populasinya seluruh mahasiswa ekonomi islam S1 angkatan 2019. Jumlah populasinya adalah 1.282 orang. Untuk menentukan sampel penelitian ini peneliti menggunakan rumus slovin, sebagai berikut :

$$
\mathrm{n}=\frac{N}{1+N e^{2}}
$$

Dimana :

$\mathrm{n}=$ jumlah sampel

$\mathrm{N}=$ jumlah populasi

$\mathrm{e}=$ batas toleransi kesalahan (error tolerance)

Jadi jika jumlah populasi dalam penelitian ini 30 orang sementara tingkat kesalahan yang dikehendaki adalah $1 \%$ maka jumlah sampel yang diambil sebagai berikut :

$$
\begin{gathered}
n=\frac{1.282}{1+1.282(0,1)^{2}} \\
n=\frac{1.282}{12.82} \\
\mathrm{n}=100
\end{gathered}
$$

Jadi jumlah sampel yang dibutuhkan dalam penelitian ini adalah 100 Mahasiswa FEBI UIN. Sedangkan pengambilan sampling nya digunakan sampel yang representatif adalah secara acak atau random. Dalam penelitian ini pengambilan sampel dilakukan dengan teknik probability sampling, yaitu dengan teknik pengambilan sampel yang memberikan peluang yang sama bagi setiap unsur (anggota) populasi untuk dipilih menjadi anggota sampel (Lestari 2014).

Setelah data terkumpul, maka penulis akan melakukan uji instrumen yaitu uji validitas dan reliabilitas untuk mengetahui item-item pernyataan yang memenuhi kriteria validitas dan reliabilitas sehingga dapat dilakukan uji prasyarat analisis yaitu dengan tahapan uji normalitas, uji linearitas dan uji multikolinearitas untuk mengetahui apakah analisis data untuk pengujian hipotesis dapat dilanjutkan atau tidak. Lalu analisis data dilakukan dengan menggunakan teknik analisis deskriptif uji mengetahui bagaimana tingkat literasi keuangan dan analisis regresi sederhana menggunakan bantuan alat statistic yaitu SPSS 15.0

Variabel yang dikaji dalam penelitian ini adalah "Pengaruh Iklan Cash Card Terhadap minat Mahasiswa ekonomi islam S1 angkatan 2019". Variabel yang digunakan yaitu :

a. Pengaruh iklan cash card sebagai variabel bebas $(\mathrm{X})$ atau variabel yang mempengaruhi

b. Terhadap minat mahasiswa ekonomi islam sebagai variabel terikat (Y) atau Variabel yang dipengaruhi

\section{HASIL DAN PEMBAHASAN} berikut :

Dalam penelitian ini, didapatkan hasil penyebaran kuesioner dari 100 mahasiswa sebagai

Tabel 1. Karakteristik Responden Mahasiswa Aktif Ekonomi Islam FEBI UINSU 


\begin{tabular}{|c|c|c|c|}
\hline NO & Karakteristik & Jumlah & Persentase \\
\hline \multirow[t]{5}{*}{1} & Program Studi & & \\
\hline & Ekonomi islam & 100 & $100 \%$ \\
\hline & Asuransi syariah & - & - \\
\hline & Manajemen syariah & - & - \\
\hline & Perbankan syariah & - & - \\
\hline \multirow[t]{3}{*}{2} & Jenis Kelamin & & \\
\hline & Perempuan & 70 & $70 \%$ \\
\hline & Laki-Laki & 30 & $30 \%$ \\
\hline \multirow[t]{4}{*}{3} & Pendapatan Perbulan & & \\
\hline & $50.000-100.000$ & 30 & $30 \%$ \\
\hline & $>500.000$ & 50 & $50 \%$ \\
\hline & $<2.000 .000$ & 20 & $20 \%$ \\
\hline \multirow[t]{4}{*}{4} & Pengeluaran Perbulan & & \\
\hline & $>500.000$ & 79 & $79 \%$ \\
\hline & $1.000 .00-2.000 .00$ & 11 & $11 \%$ \\
\hline & $<5.000 .00$ & 10 & $10 \%$ \\
\hline \multirow[t]{3}{*}{5} & Mengetahui Kartu Plastik Syariah & & \\
\hline & Ya & 79 & $79 \%$ \\
\hline & Tidak & 21 & $21 \%$ \\
\hline \multirow[t]{5}{*}{6} & $\begin{array}{l}\text { Produk Kartu Plastik Syariah } \\
\text { Yang Pernah Digunakan }\end{array}$ & & \\
\hline & BRI Syariah & 32 & $32 \%$ \\
\hline & BSI & 21 & $21 \%$ \\
\hline & Bank Sumut Syariah & 15 & $15 \%$ \\
\hline & DLL & 32 & $32 \%$ \\
\hline
\end{tabular}
A. Analisis Data
1. Uji Deskriptif

\section{Statistics}




\begin{tabular}{|c|c|c|}
\hline \multirow{3}{*}{$\mathrm{N}$} & lan cash c & \\
\hline & \multirow{2}{*}{$\begin{array}{l}\text { Valid } \\
\text { Missing }\end{array}$} & 100 \\
\hline & & 0 \\
\hline Mean & & 15,4900 \\
\hline Std.Deviation & & 3.90931 \\
\hline Variance & & 15.283 \\
\hline Skewness & &, 093 \\
\hline Std.Error of skewness & & ,241 \\
\hline Kurtosis & &,- 285 \\
\hline Std.Error of kurtosis & &, 478 \\
\hline Range & & 20.00 \\
\hline Maximum & & 25.00 \\
\hline Minimum & & 5.00 \\
\hline Sum & & 15.4900 \\
\hline
\end{tabular}

Tabel 2. Uji Deskriptif Pengaruh Iklan Cash Card ( X ) Mahasiswa Ekonomi Islam FEBI UIN Sumatera Utara

Statistics

Minat mahasiswa ekonomi islam( Y )

\begin{tabular}{|c|c|}
\hline Valid & 100 \\
\hline Missing & 0 \\
\hline Mean & 14.9900 \\
\hline Std.Deviation & 6.52345 \\
\hline Variance & 42.555 \\
\hline Skewness &, 068 \\
\hline Std.Error of skewness & ,241 \\
\hline Kurtosis & -1.079 \\
\hline Std.Error of kurtosis &, 478 \\
\hline Range & 20.00 \\
\hline Maximum & 25.00 \\
\hline Minimum & 5.00 \\
\hline Sum & 14.9900 \\
\hline
\end{tabular}

Tabel 3. Uji Deskriptif Minat Mahasiswa Ekonomi Islam ( Y ) Mahasiswa Ekonomi Islam FEBI UIN Sumatera Utara

2. Uji Linearitas

ANOVA Table

\begin{tabular}{l|l|l|r|r|r|r|r} 
& \multicolumn{2}{l|}{} & \multicolumn{1}{l|}{$\begin{array}{l}\text { Sum of } \\
\text { Squares }\end{array}$} & \multicolumn{1}{c|}{ df } & Mean Square & F & Sig. \\
\hline $\begin{array}{l}\text { minat mahasiswa * } \\
\text { pengaruh iklan }\end{array}$ & $\begin{array}{l}\text { Between } \\
\text { Groups }\end{array}$ & (Combined) & 16671.991 & 17 & 980.705 & 1.585 & .087 \\
\hline & & Linearity & 2261.979 & 1 & 2261.979 & 3.656 & .059 \\
\hline & & $\begin{array}{l}\text { Deviation from } \\
\text { Linearity }\end{array}$ & 14410.012 & 16 & 900.626 & 1.456 & .137 \\
\hline & Within Groups & 50735.849 & 82 & 618.730 & & \\
\hline & Total & 67407.840 & 99 & & & \\
\hline
\end{tabular}

Table 4. Uji linearitas Minat Mahasiswa (y) Pengaruh iklan (x) Mahasiswa Ekonomi Islam FEBI UIN Sumatera Utara 
Jika nilai deviation from linearity sig,> 0,05 maka ada hubungan yang linear secara signifikan antara variabel independen dengan variabel dependent. Sedangkan jika nilai deviation from linearity sig, $<0,05$ maka tidak ada hubungan yang linear secara signifikan antara variabel independen dengan variabel dependent.

Dari output di atas diperoleh nilai deviation from linearity sig, adalah 0,137>0,05. Dapat disimpulkan adanya hubungan linear secara signifikan antara variabel pengaruh iklan (X) dengan minat mahasiswa $(\mathrm{Y})$.

\section{B. UJI ASUMSI KLASIK}

\section{Uji normalitas}

a. Uji normalitas metode grafik histogram

Histogram

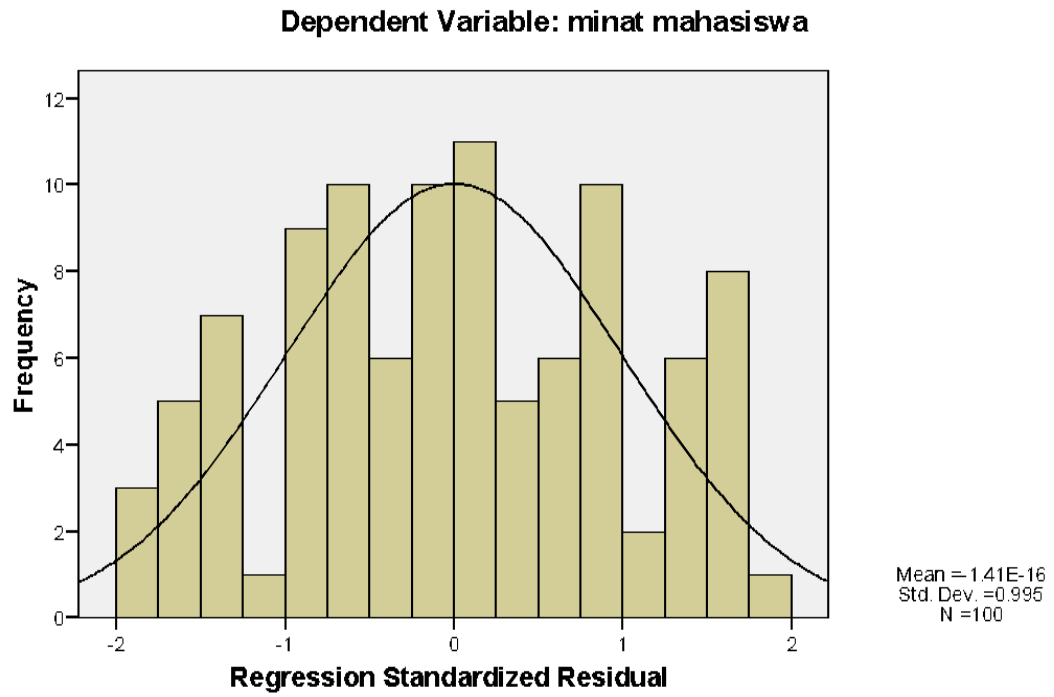

Pada grafik histogram di atas, terlihat bahwa pola distribusi data normal dan (sesuai pola).

\section{b. Uji Normalitas Metode Grafik Normal P-Plot}

Normal P-P Plot of Regression Standardized Residual

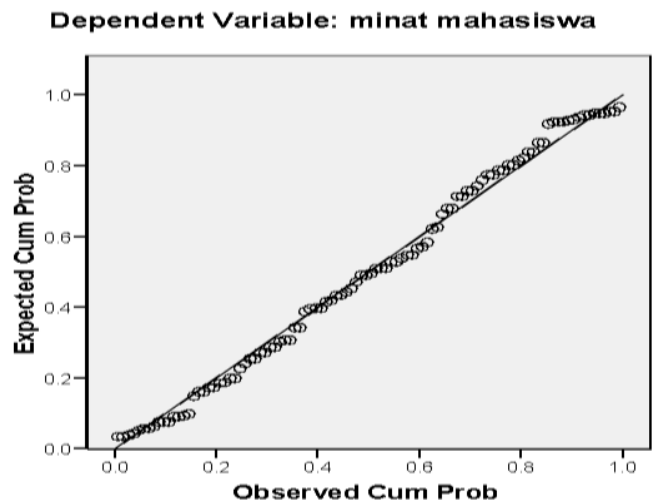

Dari hasil uji gambar normal p-plot menunjukkan bahwa titik menyebar disekitar garis diagonal dan mengikuti arah garis histogram menuju pola distribusi normal, maka variabel dependent memenuhi asumsi normalitas.

\section{c. Uji Normalitas Metode Kolmogorov-Smirnov}

One-Sample Kolmogorov-Smirnov Test 


\begin{tabular}{llr} 
& & $\begin{array}{c}\text { Unstandardized } \\
\text { Residual }\end{array}$ \\
\hline $\mathrm{N}$ & Mean & 100 \\
Normal Parameters(a,b) & Std. Deviation & .0000000 \\
Most Extreme Differences & Absolute & 25.65227080 \\
& Positive & .068 \\
& Negative & .053 \\
Kolmogorov-Smirnov Z & & -.068 \\
Asymp. Sig. (2-tailed) & & .683 \\
A Test Distribution Is Normal. & .740 \\
\hline B Calculated From Data. &
\end{tabular}

Table 5. Uji Normalitas Metode Kolmogorov-Smirnov Mahasiswa Ekonomi Islam FEBI UIN Sumatera Utara

Nilai sig uji normalitas kolmogorov-smirnov 0,740 berarti lebih besar dari 0,05 maka data penelitian ini terdistribusi normal.

\section{Uji Autokorelasi}

\section{Model Summary(b)}

\begin{tabular}{ll|r|r|r|r} 
Model & $\mathrm{R}$ & R Square & $\begin{array}{c}\text { Adjusted R } \\
\text { Square }\end{array}$ & $\begin{array}{c}\text { Std. Error of } \\
\text { the Estimate }\end{array}$ & Durbin-Watson \\
\hline 1 & $.183(\mathrm{a})$ & .034 & .024 & 25.783 & 2.068 \\
\hline
\end{tabular}

a Predictors: (Constant), pengaruh iklan(x)

b Dependent Variable: minat mahasiswa(y)

\section{Table 7. Uji Autokorelasi Mahasiswa Ekonomi Islam Febi Uin Sumatera Utara}

Dilihat dari table output diatas diketahui nilai durbin-watson sebesar 2.068. selanjutnya nilai akan dibandingkan dengan nilai tabel durbin-watson pada signifikan 5\%. Nilai durbin-watson sebesar 2.068 lebih besar dari batas $(\mathrm{du})$ yakni 1.6944 dan lebih kecil dari $(4-\mathrm{du})(4-1.6944)=2,305$ bisa diringkas $1.6944<$ $2.068<2,305$ artinya data terhindar dari gejala autokorelasi.

\section{Uji Heteroskedastisitas Metode Uji Glejser}

\begin{tabular}{|c|c|c|c|c|c|c|}
\hline \multirow[b]{3}{*}{ Mod } & & \multicolumn{5}{|c|}{ Coefficients(a) } \\
\hline & & \multicolumn{2}{|c|}{$\begin{array}{l}\text { Unstandardized } \\
\text { Coefficients }\end{array}$} & \multirow{2}{*}{$\begin{array}{c}\text { Standardized } \\
\text { Coefficients } \\
\text { Beta }\end{array}$} & \multirow{2}{*}{$\mathrm{t}$} & \multirow{2}{*}{$\begin{array}{c}\text { Sig. } \\
\text { Std. Error } \\
\end{array}$} \\
\hline & & $\mathrm{B}$ & Std. Error & & & \\
\hline \multirow[t]{2}{*}{1} & (Constant) & 17.109 & 5.927 & & 2.886 & .005 \\
\hline & pengaruh iklan & .065 & .093 & .070 & .698 & .487 \\
\hline
\end{tabular}

a Dependent Variable: Abs_RES

table 8. uji heteroskedastisitas metode uji glejser pengaruh iklan (x) mahasiswa ekonomi islam FEBI UIN sumatera utara

berdasarkan output diatas diketahui nilai sig untuk variabel pengaruh iklan (x) adalalah 0,487. Karena nilai sig variabel diatas lebih besar dari 0,05 maka dapat disimpulkan tidak terjadi gejala heteroskedastisitas dan layak digunakan untuk menguji penelitian dengan model uji regresi linear sederhana.

\section{Uji Heteroskedastisitas Metode Scatterplot}




\section{Dependent Variable: minat mahasiswa}

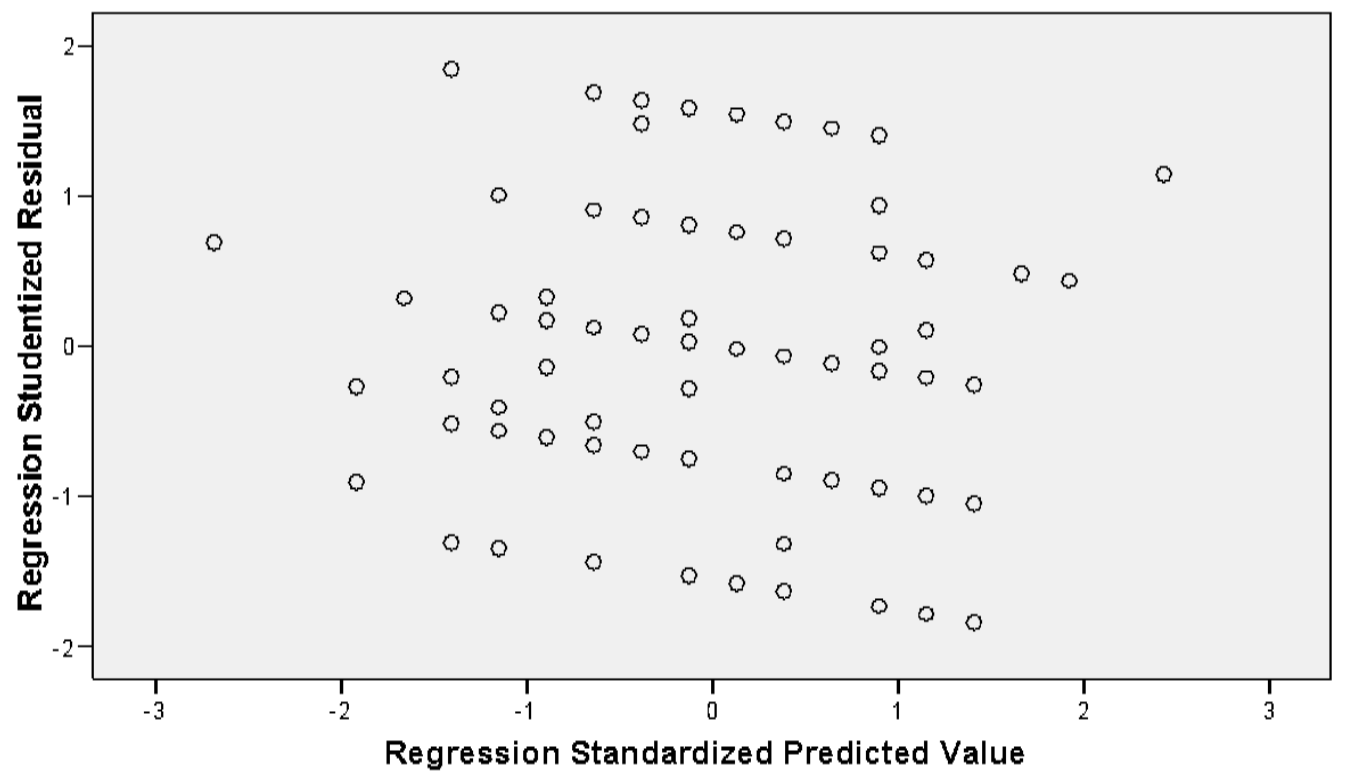

Berdasarkan dari gambar diatas dapat disimpulkan bahwa tidak terjadi gejala heteroskedastisitas, hingga model regresi yang baik dan ideal dapat terpenuhi.

\section{Uji Determinasi}

Model Summary(b)

\begin{tabular}{|c|c|c|c|c|}
\hline Model & $\mathrm{R}$ & R Square & $\begin{array}{c}\text { Adjusted R } \\
\text { Square }\end{array}$ & $\begin{array}{l}\text { Std. Error of } \\
\text { the Estimate }\end{array}$ \\
\hline 1 & $.183^{\mathrm{a}}$ & .034 & .024 & 25.783 \\
\hline
\end{tabular}

Table 9. Uji Determinasi Pengaruh Iklan (X) Minat Mahasiswa(Y) Mahasiswa Ekonomi Islam Febi Uin Sumatera Utara

Dari tabel diatas dapat dilihat bahwa nilai $\mathrm{r}$ square 0.034 atau 34\%. Angka tersebut menunjukkan bahwa kecil pengaruh variabel x terhadap variabel y secara gabungan, sedangkan 0,066 atau $66 \%$ dipengaruhi variabel lain diluar penelitian.

\section{Uji Hipotesis}

\section{Uji F (simultan)}

\section{ANOVA $^{\mathrm{b}}$}

\begin{tabular}{ll|r|r|r|r|r} 
Model & $\begin{array}{c}\text { Sum of } \\
\text { Squares }\end{array}$ & df & Mean Square & F & \multicolumn{1}{c}{ Sig. } \\
\hline 1 & Regression & 141.374 & 1 & 141.374 & 3.403 & $.068^{\mathrm{a}}$ \\
\cline { 2 - 7 } & Residual & 4071.616 & 98 & 41.547 & & \\
\cline { 2 - 7 } & Total & 4212.990 & 99 & & & \\
\hline
\end{tabular}

a Predictors: (Constant), pengaruh iklan(x)

b Dependent Variable: minat mahasiswa(y)

table 10.uji F pengaruh iklan(x) minat mahasiswa(y) mahasiswa ekonomi islam FEBI UIN sumatera utara

$$
\begin{aligned}
\text { F table } & =(k ; n-k) \\
& =(1 ; 100-1)=(1 ; 100)
\end{aligned}
$$




$$
=3,94
$$

Pengambilan keputusan dengan menggunakan $\mathrm{F}$ hitung dan $\mathrm{F}$ tabel, dapat dilihat Dari output diatas bahwa $\mathrm{F}$ hitung lebih besar daripada $\mathrm{F}$ tabel atau $(3.403>3.94)$ maka dapat disimpulkan bahwa $\mathrm{H}_{0}$ ditolak dan $\mathrm{H}_{\mathrm{a}}$ diterima dengan kata lain pengaruh iklan $(\mathrm{X})$ secara simultan berpengaruh terhadap minat mahasiswa $(\mathrm{Y})$.

\section{Uji t}

\section{Coefficients $^{\mathrm{a}}$}

\begin{tabular}{|c|c|c|c|c|c|c|}
\hline \multirow{2}{*}{\multicolumn{2}{|c|}{ Model }} & \multicolumn{2}{|c|}{$\begin{array}{l}\text { Unstandardized } \\
\text { Coefficients }\end{array}$} & \multirow{2}{*}{$\begin{array}{c}\text { Standardized } \\
\text { Coefficients } \\
\text { Beta } \\
\end{array}$} & \multirow{2}{*}{$\mathrm{t}$} & \multirow{2}{*}{ Sig. } \\
\hline & & $\mathrm{B}$ & Std. Error & & & \\
\hline \multirow[t]{2}{*}{1} & (Constant) & 10.255 & 2.647 & & 3.875 & .000 \\
\hline & PENGARUH IKLAN & .306 & .166 & .183 & 1.845 & .068 \\
\hline
\end{tabular}

a Dependent Variable: MINAT MAHASISWA(Y)

Table 11. Uji t Pengaruh Iklan (x) Minat Mahasiswa (y) Mahasiswa Ekonomi iIslam FEBI UIN Sumatera Utara

$$
\begin{aligned}
\text { t table } & =(0,05 ; 98) \\
& =1.664
\end{aligned}
$$

Berdasarkan output spss diatas dapat dilihat bahwa t hitung lebih besar daripada t tabel atau 1.845> 1.664 dapat disimpulkan bahwa $\mathrm{H}_{0}$ ditolak dan $\mathrm{H}_{\mathrm{a}}$ diterima artinya adanya pengaruh iklan cash card terhadap minat mahasiswa. Dengan menggunakan statistik deskriptif dan melalui beberapa tahapan perhitungan diketahui bahwa sebagian mahasiswa ekonomi islam FEBI UIN sumatera utara telah mengetahui pengaruh iklan cash card terhadap minat mahasiswa sebesar 15,49\% mahasiswa. setelah dilakukan uji deskriptif hingga uji t dapat disimpulkan bahwa iklan berpengaruh positif dan signifikan terhadap minat mahasiswa dalam menggunakan produk cash card ( kartu ATM).

\section{SIMPULAN}

Melihat tujuan penelitian ini yang telah dijelaskan di awal, maka dapat disimpulkan sebagai berikut : 15,49\% Mahasiswa ekonomi islam FEBI UIN sumatera utara merasa iklan sangat berpengaruh terhadap minat mahasiswa dalam menggunakan produk cash card dari salah satu bank. Terdapat pengaruh positif dan signifikan antara iklan dan minat dalam menggunakan cash card.

\section{BIBLIOGRAFI}

Decky hendarsyah(2020), analisis perilaku konsumen dan keamanan kartu kredit perbankan, jurnal perbankan syariah Vol.1, No.1: 85-96

Indah, Listiyanti. 2016. "Pengaruh Fasilitas Kerja Dan Komunikasi Kerja Terhadap Kinerja Karyawan." Jmk 1(1): 56-64.

Iska, Syukri. 2012. Sistem Perbankan Syariah Di Indonesia Dalam Perspektif Fikih Ekonomi. www.fajarmediapress.blogspot.com.

Jayusman, Iyus, and Oka Agus Kurniawan Shavab. 2020. "Aktivitas Belajar Mahasiswa Dengan Menggunakan Media Pembelajaran Learning Management System (Lms) Berbasis Edmodo Dalam Pembelajaran Sejarah.” Jurnal Artefak 7(1): 13.

Lestari, Karunia Eka. 2014. "Implementasi Brain-Based Learning Untuk Meningkatkan Kemampuan Koneksi Dan Kemampuan Berpikir Kritis Serta Motivasi Belajar Siswa SMP.” Judika (Jurnal pendidikan UNSIKA) 2(1). https://journal.unsika.ac.id/index.php/judika/article/download/120/124. 
Krisnamurti, ario bagas dan SBM, nugroho(2020), pengaruh pembayaran nontunai terhdap jumlah uang beredar dalam arti sempit (kasus volume kartu debet/ATM dan volume electronic money) periode januari 2013 sampai desember 2017

Purwaningwulan, Melly Maulin. 2013. "Daya Tarik Pesan Iklan Humor.” Majalah Ilmiah UNIKOM 10(1): 3-8.

Rahman, Sabbir, Ahasanul Haque, Mohd Ismail, and Sayyed Ahmad. 2010. "Exploring Influencing Factors for the Selection of Mobile Phone Service Providers: A Structural Equational Modeling (SEM) Approach on Malaysian Consumers." African Journal of Business Management 4(13): 2885-98.

Rachmat kriyantono, Ph.D., manajemen periklanan (teori dan praktek), maret 2013, penerbit universitas brawijaya (UB press)

Rivaldi putra prastama(2019), pengaruh efektivitas pengembangan kartu ATM "chip" terhdap tingkat kepuasan nasabah bank jatim. Tesis

Solihat, Nur Ai, and Syamsudin Arnasik. 2018. "Pengaruh Literasi Ekonomi Dan Gaya Hidup Terhadap Perilaku Konsumtif Mahasiswi Pendidikan Ekonomi Universitas Siliwangi." Oikos : Jurnal Kajian Pendidikan Ekonomi dan Ilmu Ekonomi 2(1): 141-52. 